\title{
REALITAS PENILAIAN PRAKTIK PENGALAMAN LAPANGAN PADA PERGURUAN TINGGI KEAGAMAAN ISLAM DAN TANTANGANNYA DI ERA MILLENIAL
}

\author{
Lian G. Otaya \\ IAIN Sultan Amai Gorontalo \\ lianotaya82@iaingorontalo.ac.id
}

\begin{abstract}
ABSTRAK
Studi ini bertujuan mengungkap realitas penilaian pelaksanaan PPL Mahasiswa pada Perguruan Tinggi Keagamaan Islam (PTKI) Fakultas IImu Tarbiyah dan Keguruan sebagai bagian dari Lembaga Pendidikan Tenaga Kependidikan Islam (LPTKI) dengan kesiapan mahasiswa menjadi guru di Era Millenial. Metode penelitian yang digunakan adalah penelitian kualitatitif dengan pendekatan studi kasus. Data dikumpulkan melalui focus group discussion(FGD), observasi dan dokumentasi. Hasil penelitian menunjukkan bahwa hasil penilaian pelaksanaan PPL yang diperoleh mahasiswa selama ini belum mampu menggambarkan kompetensi yang dipersyaratkan menjadi guru yaitu kompetensi pedagogik, profesional, sosial dan kepribadian. Hal ini dipengaruhi model penilaian yang digunakan dalam buku panduan untuk mengukur kompetensi mahasiswa PPL belum terdeskripsi lengkap dan detail, masih banyak indikator-indikator yang belum dapat ternilai oleh instrumen yang sudah ada dengan rubrik penskoran yang jelas dan ini menjadi realitas yang dihadapi di berbagai PTKI Indonesia.Perlu dilakukan pengembangan model penilaian PPL yang didesain secara sederhana dan mudah diaplikasikan oleh dosen pembimbing dan guru pamong dalam melakukan penilaian.Konstruk dan indikator dari item-item instrumen penilaian PPL dikembangkan mengacu pada standar kompetensi PPL yang dirumuskan berdasarkan tuntutan kompetensi guru.
\end{abstract}

Kata Kunci:Penilaian, PPL, Mahasiswa, PTKI, Kesiapan menjadi Guru

\begin{abstract}
This study aims to reveal the assessment reality of students' teaching practice program at the Islamic University, especially in Faculty of Teaching Training and Education as a part of Islamic teacher education institution with the readiness of students of being a teacher in millennium era. This research used qualitative method with a case study approach. Data was obtained through focus group discussion(FGD), observation, and documentation. The research result showed that the result of teaching practice program's
\end{abstract}


assessment obtained by students was unable to describe the required competences to be a teacher, they are: pedagogy competence, professional competence, social competence, and personality competence. This thing was influenced by the assessment model used in guiding book to measure the competence of students' teaching practice program, and it has not been completely described in detail. There were many indicators which could not be measured by the instrument with an obvious scoring rubric and this thing became a reality which should be faced at all Islamic teacher education institutions in Indonesia. It was urgently needed to do a development of the assessment of teaching practice program which was simply designed and easy to be implemented by the supervisor lecturer and supervisor teacher in doing an assessment. Construct and indicator from the instrument items of teaching practice program assessment were developed by referring to teaching practice program competence standard which was formulated based on the teacher competence.

Keywords:Assessment, Teaching Practice Program (PPL), Students, Islamic teacher education institution, The readiness to be a teacher 


\section{PENDAHULUAN}

Pendidikan merupakan suatu usaha yang dinamis dalam kehidupan setiap individu dalam rangka pembentukan diri secara utuh dan proses pengembangan kemampuan secara keseluruhan. Sehingga pendidikan saat ini sangat kompleks, sertaperlu dipandang sebagai bagian unsur penting dalam kehidupan. Proses pendidikan memiliki cakupan luas, baik dalam dimensi ataupun substansi yang memungkinkan setiap jenjang dan jalur pendidikan untuk mengembangkan potensigenerasi bangsa secara optimal. Masing-masing lembaga pendidikan menetapkan karakteristik dan kekhasan programnya termasuk dalam menyiapkan calon guru yang memiliki kualifikasi akademik dan kompetensi guru sebagaimana dalam Undang-Undang Nomor 14 Tahun 2005 tentang Guru dan Dosen.

Mengembangkan kualitas guru adalah tanggung jawab perguruan tinggi yang menyediakan program pendidikan guru, tanpa membedakan apakah dari perguruan tinggi negeri maupun swasta. Wilkerson \& Lang (2007: 2) berpendapat semua perguruan tinggi yang menyediakan layanan pendidikan guru harus memenuhi standar yang sama untuk meningkatkan kualitas pengajaran dari seorang gurudi masa kini dan masa depan. Oleh karena itu, peran perguruan tinggi sebagai bagian dari LPTK yang bertugas mencetak lulusan calon-calon guru yang berkualitas di Indonesia sangat dibutuhkan, tak terkecuali Lembaga Pendidikan Tenaga Pendidikan Islam (LPTKI) pada Perguruan Tinggi Keagamaan Islam (PTKI) yaitu Fakultas IImu Tarbiyah dan Keguruan.

Keberadaan Fakultas IImu Tarbiyah dan Keguruan sebagai lembaga pencetak guru saat ini mengalami tantangan sangat kompleks dalam hal menghasilkan calon guru yang profesional dan adanya kebijakan pemerintah terkait pengadaan guru yang harus dipandang sebagai bagian dari suatu unsur penting dalam konstelasi dan proses pengadaan guru sesuai angka kebutuhan guru. Berdasarkan data tahun 2017, AngkaKebutuhan Guru (AKG) secara keseluruhan dari semua provinsi di Indonesia sebanyak 492.765. Sementara untuk kebutuhan guru PendidikanAgama Islam secara nasional menunjukkan angka yang cukup fantastis. Berdasarkan data EMIS 2015/2016, jumlah peserta didik muslim yang belajar di sekolah (SD, SMP, SMA dan SMK) secara total sebanyak 37.655.118 jiwa. Sementara, jumlah guru yang tersedia sebanyak 182.696 orang. Jumlah guru tersebut secara ideal semestinya berjumlah 217.738 guru. Hal itu menunjukkan terdapat kekurangan sekitar 35.042 guru. Kekurangan tersebut menurut data sementara semakin bertambah di tahun 2017 , 
diperkirakan ada sekitar 55 ribu guru Pendidikan Agama Islam yang akan memasuki purna bhakti atau pensiun, dan yang sedang mengusulkan mutasi menjadi pengawas (Republika, 2017). Ini mengindikasikan perlu kerja keras dan komitmen Fakultas IImu Tarbiyah dan Keguruan sebagai LPTKI dalam menghasilkan calon guru berkualitas sesuai kebutuhan masyarakat.

Kebutuhan masyarakat akan guru berkualitas, mendorong Fakultas IImu Tarbiyah dan Keguruan terus melakukan terobosan dalam hal pengelolaan serta menyiapkan model pendidikan yang diterapkan. Salah satunya melalui model pendidikan keguruan berbasis kolaborasi antara mahasiswa praktikan, dosen pembimbing, dan guru pamong dalam pelaksanaan Praktik Pengalaman Lapangan (PPL). PPL pada Fakultas IImu Tarbiyah dan Keguruan merupakan media untuk mengaplikasikan teori-teori kependidikan dalam kegiatan nyata di lapangan dalam usaha menyiapkan lulusan yang profesional di bidang kependidikan dan pengajaran. Hal ini didukung oleh beberapa kajian yang menyatakan bahwa PPL merupakan program pendidikan dan langkah penting dalam mempersiapkan mahasiswa menjadi calon guru (Muhammad, 2011, Butler \& Cuenca, 2012, Gareis \& Grant, 2014). Maka proses kegiatan PPLdiarahkan untuk melatih kemampuan mahasiswa mengajar secara langsung, terjadwal, dan sistematis sesuai prosedur serta syarat yang ditetapkan (Yulianto \& Kafid, 2016). Sehingga esensi penting dari PPL, memberikan kesempatan mahasiswa untuk mengenal dunia keguruan secara nyata dalam mengintegrasikan teori dan praktik mengajar sebelum mereka benar-benar terjun di dunia pendidikan secara langsung.

Kesiapan mahasiswa menjadi guru hingga saat ini kontradiksi dengan harapan pelaksanaan PPL dan penilaian yang ada.Seharusnya dengan nilai yang baik para mahasiswa dianggap telah siap menjadi seorang guru, namun realitanya masih terdapat berbagai permasalahan dalam pelaksanaannya. Hal ini didukung dengan berbagai penelitian terhadap pelaksanaan PPL mahasiswa pada program pendidikan guru secara umum belum mampu melatih mahasiswa menerapkan pengetahuan dan kemampuan untuk menjadi seorang guru yang berkompeten (Cohen, Hoz, \& Kaplan, 2013; Ku, Kaufeld, Hess, \& Sheehan, 2012; Whitebook et al., 2012). Dengan demikian, diasumsikan apa yang menjadi tujuan dan sasaran dari pelaksanaan PPL masih jauh dari harapan.

Demikian halnya pelaksanaan PPL mahasiswa diberbagai Fakultas IImu Tarbiyah dan Keguruan di Indosesia tidak lepas dari permasalahan yang dihadapi 
pada sekolah/madrasah tempat praktik yang secara tidak langsung menyebabkan kegiatan PPL menjadi kurang maksimal. Meskipun dalam praktiknya telah mengikuti prosedur yang dirumuskan secara spesifik dalam buku panduan yang menjadi kerangka acuan dalam mengkaji data deskriptif program, namun secara internal belum terjadi koherensi antar unsur karena input sumber manusiawi (pelaksana) belum maksimal melaksanakan program dan masih bersifat temporer (kepanitian). Padahal Moseley \& Hastings (2005: 8) menyebutnya "implementation is viewed as the weakest in the intervention selection and design process". Variasi konteks dan pelaksana saat program diimplementasikan sangat menentukan keberhasilannya. Oleh karena itu pelaksanaan PPL sangat membutuhkan konteks dan pelaksana yang berkualitas, terutama Dosen Pembimbing dan Guru Pamong harus mampu mengungkap capaian kompetensi mahasiswa praktikan secara utuh.

Mencermati permasalahan di atas, secara eksplisit diperlukan adanya perhatian dan perbaikan yang kontinu dan berkelanjutan untuk membuat PPL ini lebih efektif dan bermanfaat, karena jika semakin baik pelaksanaan PPL mahasiswa, maka semakin baik pula kemampuan mengajar mahasiswa untuk mendukung kesiapannya menjadi guru. Namun berdasarkan kajian penelitian yang dilakukan terkait pelaksanaan PPL di Fakultas IImu Tarbiyah dan Keguruan, tidak banyak yang mengkaji permasalahan ini. Salah satunya temuan menunjukkan PPL Jurusan Pendidikan Agama Islam Fakultas IImu Tarbiyah UIN Sunan Kalijaga Yogyakarta memiliki beberapa kelemahan. Seperti persoalan evaluasi dilakukan sangat beragam tanpa penskoran yang jelas, banyak guru pamong yang kurang memiliki kompetensi pedagogik maupun professional, tidak memiliki persiapan pembelajaran, sehingga kurang maksimal dalam membimbing mahasiswapraktikan. Selain itu penilaian PPL lebih banyak fokus pada pelaporan kegiatan PPL saja. Apabila hasil laporannya baik dan lengkap nilai yang diperoleh pasti baik, sehingga tidak memberikan hasil yang optimal (Rofiq, 2008: 119). Sedang target PPL adalah terbentuknya mahasiswa yang memiliki 4 (empat) kompetensi, yaitu personal, sosial, profesional dan pedagogik.

Permasalahan yang sama juga dihadapi oleh Fakultas IImu Tarbiyah dan Keguruan UIN Syarif Hidayatullah Jakarta, menurut Tim Penyusun Pedoman Praktik Profesi Keguruan Terpadu (PPKT) FITK UIN Syarif Hidayatullah Jakarta (2010: 2) bahwa selama ini pelaksanaan PPL yang diharapkan dapat memberikan pengalaman awal bagi praktikan belum dapat berjalan secara optimal. Indikasinya adalah semakin kerasnya kritik dari para pengguna (user) terhadap kompetensi profesional alumni 
FITK UIN Syarif Hidayatullah Jakarta. Rendahnya kompetensi tersebut, menunjukkan kurangnya bekal pengalaman yang diberikan kepada mereka.

Permasalahan yang sama terjadi pula pada pelaksanaan PPL Mahasiswa Fakultas IImu Tarbiyah Dan Keguruan IAIN Walisongo Semarang. Adanya kendala soal pemahaman teknis penilaian yang dilakukan oleh dosen pembimbing dan guru pamong dalam ujian akhir mengajar mahasiswa praktikan. Keduanya memiliki persepsi yang berbeda dalam penilaian, bahkan dosen dan guru pamong hanya memberikan nilai akhir tanpa mengisi format instrumen. Hal ini terjadi karena dalam Buku Pedoman tidak secara eksplisit diberikan contoh panduan penilaian disertai dengan rubrik penskoran sesuai dengan kompetensi yang diuji (Hashona, 2014 : 347).

Berdasarkan permasalahan penilaian PPL tersebut, hal itu mengindikasikan tujuan serta sasaran PPL tentu hakikatnya masih jauh dari harapan. Sementara jika dilihat dari hasil nilai PPL mahasiswa mayoritas lulus dan rata-rata memperoleh nilai amat baik $(A)$. Tingginya nilai PPL yang diperoleh mahasiswa mengindikasikan adanya kesenjangan antara permasalahan dalam pelaksanaan PPL dengan penilaian yang dilakukan. Hal ini salah satunya dipengaruhimodel penilaian yang digunakanbelum mampu mengungkap capaian kompetensi mahasiswa yang diharapkan dari pelaksanaan PPL. Oleh karena itu, tulisan ini fokus mengkaji evaluasi penilaian PPL mahasiswa Fakultas IImu Tarbiyah dan Keguruan yang ada pada PTKI. Sehingga dapat diidentifikasi apa yang menjadi kebutuhan mendesak untuk diperbaiki format instrument serta aspek penilaiannya. Selain itu, di Indonesia belum ada kajian yang memfokuskan pada masalah penilaian PPL khususnya di Fakultas IImu Tarbiyah dan Keguruan sehingga permasalahan ini sangat penting, urgen dan menarik untuk dikaji.

\section{METODE PENELITIAN}

Penelitian ini termasuk penelitian kualitatif mengacu pendapat Creswell (2003) dimana peneliti fokus pada usaha mempelajari makna yang disampaikan oleh partisipan berdasarkan pengalaman, cerita dan pandangan mereka sehingga diperoleh gambaran kompleks dari suatu masalah atau isu yang diteliti. Teknik pengumpulan data yang digunakan adalah focus group discussion (FGD). Teknik ini dipilih karena FGD dalam penelitian kualitatif digunakan untuk menemukan makna sebuah tema atau isu yang diteliti menurut pemahaman sebuah kelompok. Dengan demikian melalui FGD, peneliti dapat menemukan makna tentang realita penilaian 
PPL mahasiswa menurut pengalaman dan pendapat dosen pembimbing dan guru pamong. Teknik ini didukung dengan studi dokumentasi untuk mendapatkan gambaran yang riil tentang dokumen penilaian dari dosen pembimbing dan guru pamong terhadap mahasiswa praktikan dengan menggunakan model penilaian selama ini. Data dianalisis secara deskriptif kualitatif, dimana setelah dilakukan analisis berdasarkan data temuan hasil FGD yang didukung dengan studi dokumentasi, peneliti melakukan analisis secara deskriptif untuk mengkaji makna yang didapat dari hasil FGD dengan dosen pembimbing dan guru pamong sebagai informan dalam penelitian ini.

\section{PEMBAHASAN}

\section{Deskripsi Pelaksanaan PPL Mahasiswa}

Fakultas IImu Tarbiyah dan Keguruan sebagai lembaga pendidikan di PTKI bertugas mempersiapkan, serta membentuk lulusannya menjadi calon guru yang profesional. Kemampuan ini diukur dari sejauh mana para lulusan memiliki kompetensi kependidikan, baik kompetensi pedagogik, profesional, kepribadian maupun sosial. Tugas tersebut dapat dilakukan secara profesional apabila mahasiswa dibekali seperangkat ilmu maupun pengalaman baik yang bersifat teoritis maupun praktis. Pengalaman teoritis telah diberikan melalui sistem perkuliahan. Sedangkan pengalaman praktis diberikan melalui kegiatan praktik langsung di lapangan, melalui PPL.

PPLdi Fakultas IImu Tarbiyah dan Keguruan IAIN Sultan Amai Gorontalo adalah mata kuliah intrakurikuler aplikatif dan terpadu dari seluruh pengalaman belajar ke dalam program pelatihan untuk mempersiapkan mahasiswa agar memiliki kemampuan dan keterampilan keguruan, pelaksanaan kegiatan administrasi pendidikan, penelitian kependidikan dan pengabdian kependidikan. PPL di Fakultas Tarbiyah dan IImu Keguruan IAIN Tulungagungjuga merupakan merupakan matakuliah yang memberikan wawasan dan pengalaman praktis kepada mahasiswa mengenai kegiatan pembelajaran riil di kelas, sehingga menguasai berbagai kompetensi keguruan. Kegiatan pembelajaran tersebut meliputi perencanaan pembelajaran, pelaksanaan pembelajaran, dan penilaian dalam pembelajaran. PPL dilaksanakan secara terpadu, yakni di kampus PPL I dan di sekolah mitra PPL II.

PPL di Fakultas IImu Tarbiyah dan Keguruan UIN Syaruf Hidayatullah Jakarta disebut dengan Praktik Profesi Keguruan Terpadu (PPKT) adalah kegiatan akademik 
yang dilakukan mahasiswa dalam rangka menetapkan dan mengembangkan kompetensi professional, pedagogik, kepribadian dan sosial yang berwujud alam praktik keguruan, penelitian dan pengelolaan pendidikan, kinerja mahasiswa praktikum dalam aspek pengetahuan, keterampilan, sikap dan perilaku keguruan uang dialami secara nyata di madrasah/sekolah. Dengan demikian PPKT mencakup tiga dhrama perguruan tinggi sebagai mata kuliah, PPKT berbobot 6 sks yang dilaksanakan sepenuhnya di madrasah/sekolah praktik dengan ruang lingkup PPKT terdiri dari: (a) kegiatan pembelajaran di dalam kelas; (b) kegiatan pengabdian kependidikan mencakup kegiatan kependidikan, kegiatan administrasi dan kegiatan penelitian kependidikan.

PPL di Fakultas IImu Tarbiyah dan Keguruan UIN Walisongo Semarang adalah kegiatan belajar mahasiswa yang dilakukan di lapangan untuk mengintegrasikan pengetahuan teoritis yang diperoleh di kampus dengan pengalaman praktik di lapangan sehingga target khusus yang merupakan target capaian pembelajaran program studi dapat tercapai. Kegiatan tersebut meliputi pembelajaran dan pengelolaan adminstrasi di sekolah/madrasah latihan. Praktik pembelajaran adalah latihan melaksanakan kegiatan pembelajaran oleh mahasiswa di dalam kelas, mulai dari membuat perencanaan pembelajaran (RPP), pelaksanaan dan penilaian. Sedangkan praktik pengelolaan administrasi adalah latihan melaksanakan tugastugas administrasi, bimbingan dan lain-lain. Dalam melaksanakan tugas PPL mahasiswa dipandu oleh pihak sekolah/madrasah dan dibimbing oleh Dosen pembimbing.

PPL di Fakultas Tarbiyah dan Keguruan UIN Sunan Ampel Surabayaadalah suatu rangkaian kegiatan untuk menerapkan berbagai teori kependidikan yang berupa latihan-latihan pembelajaran di sekolah dan madrasah disebut dengan PPL II. Bentuk kegiatan PPL II merupakan tahap latihan mengajar yang dihadapkan padaa siswa sesungguhnya, yang dikenal dengan real classroom teachingdan latihan tugas-tugas kependidikan dan pembelajaran lainnya. Bobot mata kuliah yang berupa praktik ini adalah 4 sks. Kegiatan ini merupakan tahapan praktik mengajar yang ke dua setelah mahasiswa-mahasiswi melakukan PPL I.

Mengacu pada konsep PPL dibeberapa Fakultas IImu Tarbiyah dan Keguruan di atas, meskipun penamaan dalam pelaksanaannya berbeda namun secara garis besar PPL merupakan bagian terpadu dari proses pendidikan mahasiswa calon guru pada jenjang S1. Suatu bentuk penerjunan mahasiswa dalam situasi nyata di 
lapangan dunia pendidikan formal. Hal itu diharapkan mampu menjadi bekal sebagai calon pendidik maupun tenaga kependidikan, dimana mahasiswa mampu mendapat pengalaman tentang tugas-tugas kependidikan di sekolah/ madrasah meliputi pengelolaan pembelajaran dan wawasan kependidikan secara memadai.Jika ditilik dari tujuan PPL di Fakultas Tarbiyah dan Keguruan UIN Sunan Ampel Surabaya adalah terbentuknya kompetensi pedagogik, kepribadian, sosial dan kompetensi professional.

\section{a. Kompetensi pedagogik}

Terbentuknya kompetensi pedagogik dengan indikator: (1) Menguasai karakteristik peserta didik dari aspek fisik, moral, spiritual, sosial, kultural, emosional, dan intelektual; (2) Menguasai teori belajar dan prinsip-prinsip pembelajaran yang mendidik; (3) Mengembangkan kurikulum yang terkait dengan mata pelajaran yang diampu' (4) Menyelenggarakan pembelajaran yang mendidik; (5) Memanfaatkan teknologi informasi dan komunikasi untuk kepentingan pembelajaran; (6) Memfasilitasi pengembangan potensi peserta didik untuk mengaktualisasikan berbagai potensi yang dimiliki; (7) Berkomunikasi secara efektif, empatik, dan santun dengan peserta didik; (8) Menyelenggarakan penilaian dan evaluasi proses dan hasil belajar; (9) Memanfaatkan hasil penilaian dan evaluasi untuk kepentingan pembelajaran; (10) Melakukan tindakan reflektif untuk peningkatan kualitas pembelajaran.

b. Kompetensi Kepribadian

Terbentuknya kompetensi kepribadian dengan indikator: (1) Bertindak sesuai dengan norma agama, hukum, sosial, dan kebudayaan nasional Indonesia; (2) Menampilkan diri sebagai pribadi yang jujur, berakhlak mulia, dan teladan bagi peserta didik dan masyarakat; (3) Menampilkan diri sebagai pribadi yang mantap, stabil, dewasa, arif, dan berwibawa; (4) Menunjukkan etos kerja, tanggung jawab yang tinggi, rasa bangga menjadi guru, dan rasa percaya diri; Menjunjung tinggi kode etik profesi guru.

c. Kompetensi Sosial

Terbentuknya kompetensi sosial dengan indikator: (1) Bersikap inklusif, bertindak objektif, serta tidak diskriminatif karena pertimbangan jenis kelamin, 
agama, ras, kondisi fisik, latar belakang keluarga, dan status sosial ekonomi; (2) Berkomunikasi secara efektif, empatik, dan santun dengan sesama pendidik, tenaga kependidikan, orang tua, dan masyarakat; (3) Beradaptasi di tempat bertugas di seluruh wilayah Republik Indonesia yang memiliki keragaman social budaya; (4) Berkomunikasi dengan komunitas profesi sendiri dan profesi lain secara lisan dan tulisan atau bentuk lain.

\section{d. Kompetensi Profesional}

Terbentuknya kompetensi profesional dengan indikator: (1) Menguasai materi, struktur, konsep, dan pola pikir keilmuan yang mendukung mata pelajaran yang diampu sesuai kurikulum yang diberlakukan; (2) Menguasai kompetensi inti dan kompetensi dasar mata pelajaran yang diampu; (3) Mengembangkan materi pembelajaran yang diampu secara kreatif; (4) Mengembangkan keprofesionalan secara berkelanjutan dengan melakukan tindakan reflektif; (5) Memanfaatkan teknologi informasi dan komunikasi untuk mengembangkan diri.

Konteks pencapaian kompetensi yang telah ditetapkan di atas, PPL memiliki fungsi dan peranan yang sangat strategis. Kegiatan PPL yang dilakukan mahasiswa pada hakikatnya melakukan aktivitas belajar dengan bekerja pada suatu sekolah/lembaga pendidikan tertentu. Para mahasiswa dalam melaksanakan PPL, tidak hanya dituntut menggunakan pengetahuan dan keterampilan akademik yang telah diperoleh melalui perkuliahan sesuai dengan tuntutan nyata dalam situasi kerja, tetapi para mahasiswa juga dituntut untuk mendapat pengalaman mengajarsecara profesional serta mengintegrasikan pengalamannya ke dalam pola perilaku dirinya sebagai pribadi yang efektif dan produktif. Ruang lingkup kegiatan PPL dalam Buku Pedoman Program Pengalaman Lapangan Terpadu (PPLT) Fakultas IImu Tarbiyah dan Keguruan IAIN Sultan Amai Gorontalo terdiri atas: a) Kegiatan pembelajaran di dalam kelas, b) Kegiatan pengabdian kependidikan terdiri dari kegiatan kependidikan dan kegiatan administrasi kependidikan, c) Kegiatan kemasyarakatan, 4) Kegiatan penelitian kependidikan.

\section{Realita Penilaian PPL Mahasiswa}

Penilaian PPL mahasiswa penting untuk dilakukan dalam mencapai tujuan praktik itu sendiri yaitu mahasiswa memiliki kemampuan dan keterampilan keguruan, 
pelaksanaan kegiatan administrasi pendidikan, penelitian kependidikan dan pengabdian kependidikan secara memadai. Penilaian terhadap kegiatan PPL dilakukan untuk mendapatkan informasi secara akurat tentang tingkat pencapaian kompetensi mahasiswa praktikan dalam menjalankan tugas-tugas praktik pembelajaran di sekolah/madrasah latihan. Kegiatan praktik di sekolah/madrasah latihan meliputi: (a) Kehadiran dan kedisiplinan mahasiswa praktikan; (b) Penguasaan keterampilan pembelajaran (mencakup kompetensi pedagogik, profesional, kepribadian, dan sosial); (c) Pelaksanaan kegiatan manajemen dan administrasi sekolah/madrasah; (d) Penyusunan Laporan PPL. Dengan demikian nilai akhir PPL merupakan gabungan antara: (1) nilai pembekalan dan laporan PPL, (2) nilai pencapaian kompetensi diperoleh dari rata-rata nilai praktik pembelajaran dan nilai ujian praktik pembelajaran (oleh guru pamong dan dosen pembimbing).

Penilaian PPL mahasiswa yang dilakukan selama ini pada kompetensi pedagogik berdasarkan studi dokumen model penilaian PPL yang ada pada buku panduan dari 4 (empat) Perguruan Tinggi Keagamaan Islam di Indonesia sebagai sampel diantaranya UIN Sunan Ampel Surabaya, UIN Walisongo Semarang, dan IAIN Sultan Amai Gorontalo dan Universitas Islam Nadhlatul Ulama Jepara dideskripsikan sebagai berikut.

1. Pada UIN Sunan Ampel Surabaya penilaian kompetensi pedagogik mahasiswa praktikan terdiri dari: (a) kemampuan menguasai karakteristik peserta didik yang ditunjukkan dengan kemampuan guru dalam melayani perbedaan kemampuan individu, (b) kemampuan mengembangkan kurikulum yang terkait dengan mata pelajaran yang diampu, (c) kemampuan memanfatkan media pembelajaran, teknologi informasi dan komunikasi untuk kepentingan pembelajaran, (d) kemampuan menyelenggarakan penilaian dan evaluasi proses dan hasil belajar.

2. Pada UIN Walisongo Semarang penilaian kompetensi pedagogik mahasiswa praktikan meliputi pelaksanaan tugas-tugas pembelajaran di dalam kelas, mulai penyusunan rencana pelaksanaan kegiatan pembelajaran, melakukan penilaian proses dan hasil belajar melalui pelaksanaan sejumlah keterampilan mengajar, dengan target minimal yang harus dimiliki mahasiswa adalah: (a) mampu menyusun rencana pelaksanaan pembelajaran, (b) mampu melaksanakan proses pembelajaran sesuai dengan rencana yang telah disusun, (c) mampu mengelola pengorganisasian waktu dan peserta didik dalam pelaksanaan pembelajaran secara kretaif, dinamis, dan dialogis, (d) mampu berpikir ilmiah dan 
mengembangkan cara berpikir ilmiah dalam pembelajaran, (e) mampu menciptakan suasana pembelajaran yang bermakna dan menyenangkan, (f) mampu melaksanakan kegiatan evaluasi proses dan hasil belajar.

3. Pada IAIN Sultan Amai Gorontalo penilaian kompetensi pedagogik mahasiswa praktikan dinilai dari 8 (delapan) indikator yaitu: (a) persiapan tertulis dalam bentuk rencana pelaksanaan pembelajaran (RPP), (b) keterampilan membuka pelajaran, (c) penggunaan variasi metode dan teknik pembelajaran, (d) kualitas variasi stimulus, (e) keterampilan bertanya, (f) penggunaan media/alat bantu pembelajaran, (g) keterampilan menutup pembelajaran, (h) evaluasi pembelajaran.

4. Pada Universitas Islam Nadhlatul Ulama Jepara penilaian kompetensi pedagogik mahasiswa praktikan dinilai pada komponen: (a) perencanaan pembelajaran, (b) pelaksanaan pembelajaran, (c) pengelolaan kelas, dan (d) penilaian.

Berdasarkan komponen penilaian kompetensi pedagogik mahasiswa PPL tersebut, menurut analisis rasional indikator untuk mengukur kompetensi ini kurang lengkap dan kurang detail. Masih banyak indikator-indikator yang belum dapat ternilai oleh instrumen yang sudah ada dengan rubrik penskoran yang tepat. Penilaian kompetensi pedagogik perlu dikembangkan meliputi kemampuan mahasiswa praktikan dalam mengenal karakteristik dan potensi peserta didik, menguasai teoriteori belajar dan prinsip pembelajaran yang efektif, menguasai perencanaan dan pengembangan kurikulum, menguasai langkah-langkah pembelajaran yang efektif, dan menguasai sistem dan mekanisme dan prosedur penilaian.

Penilaian kompetensi profesional guru jika merujuk pada Lampiran Permendiknas Nomor 16 Tahun 2007 tentang standar kualifikasi akademik dan kompetensi guru serta merujuk pada peraturan menteri pendidikan dan kebudayaan Republik Indonesia Nomor 57 tahun 2012 tentang uji kompetensi guru, maka kompetensi profesional guru mencakup: 1) menguasai materi, struktur, konsep, dan pola pikir keilmuan yang mendukung mata pelajaran yang diampu sesuai kurikulum yang diberlakukan, 2) menguasai kompetensi inti dan kompetensi dasar mata pelajaran yang diampu, 3) mengembangkan materi pembelajaran yang diampu secara kreatif; 4) mengembangkan keprofesionalan secara berkelanjutan dengan melakukan tindakan reflektif; 5) memanfaatkan teknologi informasi dan komunikasi untuk mengembangkan diri. 
Mengacu pada peraturan di atas, maka idealnya penilaian kompetensi profesional mahasiswa PPL mencakup komponen kompetensi profesional yang dipersyaratkan. Namun pada buku panduan praktik pengalaman lapangan yang digunakan selama ini hanya mencakup 2 komponen yaitu: 1) kualitas penguasaan materi, dan 2) kualitas penjelasan materi. Indikator kualitas penguasaan materi yang dinilai yaitu: (a) substansi materi, (b) hubungan dengan pengetahuan yang relevan atau dengan realita (kontekstual), (c) menggunakan dalil, rumus atau generalisasi. Indikator kualitas penjelasan materi yang dinilai yaitu: (a) penggunaan bahasa yang baik dan benar, (b) penggunaan contoh/ilustrasi/media yang efektif, (c) sistematika (pola induktif dan deduktif). Dengan demikian, terdapat beberapa komponen kompetensi professional yang tidak dinilai yaitu mengembangkan materi pembelajaran yang diampu secara kreatif, melakukan tindakan reflektif, dan memanfaatkan teknologi informasi dan komunikasi.

Berdasarkan analisis rasional indikator untuk mengukur kompetensi profesional dari mahasiswa praktik pengalaman lapangan tersebut kurang lengkap dan kurang detail, masih banyak indikator-indikator yang belum dapat ternilai oleh instrumen yang sudah ada dengan rubrik penskoran yang tepat. Penilaian kompetensi profesional mahasiswa praktikan dapat dinilai secara lengkap, jika memperhatikan item-item yang ada pada instrumen yang digunakan dalam menilai kompetensi profesional guru di Indonesia seperti instrumen pada uji kompetensi guru dan instrumen penilaian kinerja guru kelas/mata pelajaran. Oleh karena itu, penilaian kompetensi profesional mahasiswa praktik pengalaman lapangan di Fakultas IImu Tarbiyah dan Keguruan dikembangkan mencakup komponen: menguasai materi, struktur, konsep, dan pola pikir keilmuan yang mendukung mata pelajaran yang diampu sesuai kurikulum yang diberlakukan, menguasai kompetensi inti dan kompetensi dasar mata pelajaran yang diampu, mengembangkan materi pembelajaran yang diampu secara kreatif, melakukan tindakan reflektif dan memanfaatkan teknologi informasi dan komunikasi.

Selanjutnya penilaian kompetensi kepribadian mahasiswa PPL pada buku panduan Fakultas IImu Tarbiyah dan Keguruan bertujuan untuk membekali mahasiswa praktikan memiliki kemampuan yang berhubungan dengan sikap dan kepribadian yang harus dimiliki oleh mahasiswa sebagai calon guru. Target minimal kompetensi kepribadian yang harus dimiliki mahasiswa setelah mereka melaksanakan praktik adalah: 1) menunjukkan sikap dewasa dalam berfikir dan bertindak, 2) memiliki perilaku dan bertutur kata sopan, 3) memiliki perilaku ilmiah 
sebagai seorang akademisi, 4) menunjukkan rasa tanggung jawab yang tinggi dalam melaksanakan tugas, 5) memiliki kedisiplinan yang tinggi dalam melaksanakan tugas dan kewajiban, 6) mampu menampilkan diri sebagai calon guru yang baik.

Penilaian kompetensi kepribadian guru jika merujuk pada Lampiran Permendiknas Nomor 16 Tahun 2007 tentang standar kualifikasi akademik dan kompetensi guru serta merujuk pada peraturan menteri pendidikan dan kebudayaan Republik Indonesia Nomor 57 tahun 2012 tentang uji kompetensi guru, maka kompetensi profesional guru mencakup: 1) bertindak sesuai dengan norma agama, hukum, sosial, dan kebudayaan nasional Indonesia, 2) menampilkan diri sebagai pribadi yang jujur, berakhlak mulia, dan teladan bagi peserta didik dan masyarakat, 3) menampilkan diri sebagai pribadi yang mantap, stabil, dewasa, arif, dan berwibawa, 4) menunjukkan etos kerja, tanggung jawab yang tinggi, rasa bangga menjadi guru, dan rasa percaya diri; 5) menjunjung tinggi kode etik profesi guru.

Mengacu pada peraturan di atas, maka idealnya penilaian kompetensi kepribadian mahasiswa PPL mencakup komponen kompetensi kepribadian yang dipersyaratkan di atas. Namun pada buku panduan praktik pengalaman lapangan yang digunakan selama ini dalam menilai kompetensi kepribadian dinilai dari 10 indikator yaitu: 1) kepemimpinan dalam kelompok kerja, 2) tanggung jawab pada penyelesaian pekerjaan, 3) kematangan emosi dalam bertindak dan bertutur kata, 4) sosialisasi diri dalam lingkungan sekolah dan masyarakat, 5) disiplin dalam menjalankan tugas, 6) kerjasama antar kelompok, 7) kreativitas dan inovasi yang digagas dalam kelompok, 8) cara berbusana dan etiket di lingkungan sekolah \& masyarakat, 9) kebersihan diri dan posko kerja, 10) ketauladan di lingkungan sekolah dan masyarakat.

Menurut analisis rasional indikator untuk mengukur kompetensi kepribadian dari mahasiswa praktik pengalaman lapangan tersebut kurang lengkap dan kurang detail, masih banyak indikator-indikator yang belum dapat ternilai oleh instrumen yang sudah ada. Selama ini dosen pembimbing dan guru pamong dalam melakukan penilaian kompetensi kepribadian mengalami kesulitan karena indikator yang dinilai masih bersifat umum belum terdeskripsi secara jelas dan rinci, sehingga model penilaian kompetensi kepribadian yang ada belum mampu memberikan informasi yang akurat dan konsisten atas capaian kompetensi kepribadian yang dimiliki mahasiswa meskipun digunakan setiap praktik. Oleh karena itu, diperlukan 
pengembangan instrumen penilaian kompetensi kepribadian mahasiswa praktikan yang dapat mengungkap kompetensi tersebut secara lengkap.

Penilaian kompetensi kepribadian mahasiswa praktikan dapat dinilai secara lengkap, jika memperhatikan item-item yang ada pada instrumen yang digunakan dalam menilai kompetensi kepribadian guru di Indonesia seperti instrumen pada uji kompetensi guru dan instrumen penilaian kinerja guru kelas/mata pelajaran. Oleh karena itu, penilaian kompetensi kepribadian mahasiswa praktik pengalaman lapangan di Fakultas IImu Tarbiyah dan Keguruan dikembangkan meliputi kemampuan bertindak sesuai dengan norma agama, hukum, sosial, dan kebudayaan nasional Indonesia, menampilkan diri sebagai pribadi yang jujur, berakhlak mulia, dan teladan bagi peserta didik dan masyarakat, menampilkan diri sebagai pribadi yang mantap, stabil, dewasa, arif, dan berwibawa, menunjukkan etos kerja, tanggung jawab yang tinggi, rasa bangga menjadi guru, dan rasa percaya diri, menjunjung tinggi kode etik profesi guru.

Kompetensi yang tidak kalah penting dimiliki seorang guru adalah kompetensi sosial. Khuziakhmetov (2016) mengakui kompetensi sosial sebagai prioritas utama dalam pendidikan dan sebagai faktor penting yang dipertimbangkan dalam tatanan sosial seperti komunikasi, pengakuan, pernyataan diri, tekad diri dan lain-lain, termasuk pada mahasiswa praktik pengalaman lapangan. Kompetensi sosial mahasiswa tidak hanya dikembangkan pada lingkungan sekolah dimana mahasiswa tersebut praktik mengajar, tetapi juga harus dapat mengembangkannya dalam kehidupan sehari-hari, agar senantiasa memiliki kemampuan dalam berkomunikasi baik di lingkungan sekolah maupun di luar sekolah dengan peserta didik, guru lain, kepala sekolah, dan masyarakat luas, sehingga kompetensi ini penting untuk dinilai.

Penilaian kompetensi sosial pada mahasiswa praktikan sangat penting untuk dinilai, karena bertujuan untuk membekali mahasiswa praktikan memiliki kemampuan yang berhubungan dengan cara menempatkan diri dalam lingkungan sekolah latihan maupun cara menjalin hubungan dengan orang lain. Mengingat kompetensi ini merupakan kemampuan guru berkomunikasi dan berinteraksi secara efektif dan menarik serta kemampuan guru dalam menjalin relasi yang positif, empatik, dan santun (Sagala, 2011: 38, Mahanani, 2011: 54). Oleh karena itu, penilaian kompetensi sosial mahasiswa dalam pelaksanaan praktik pengalaman lapangan tidak biasa diabaikan, karena melalui penilaian pada kompetensi ini akan mampu mengungkap 
kecakapan dan keluwesan seorang mahasiswa dalam bersosialisasi dengan lingkungan sekitarnya mencakup hubungannya dengan sesama.

Menurut buku panduan praktik pengalaman lapangan Fakultas IImu Tarbiyah dan Keguruan, target minimal yang diharapkan dimiliki mahasiswa praktikan pada kompetensi sosial adalah: 1) mampu berkomunikasi secara baik dengan orang lain (panitia PPL, dosen pembimbing lapangan, kepala sekolah/madrasah, guru pamong, guru, peserta didik, komite sekolah/ madrasah, orang tua, dan masyarakat sekitar sekolah/madrasah), 2) mampu bekerjasama sama dengan seluruh komponen sekolah/madrasah latihan maupun antar mahasiswa praktikan, 3) berpartisipasi secara aktif dalam kegiatan-kegiatan yang diselenggarakan oleh pihak fakultas, sekolah/madrasah latihan, dan kelompok praktikan, 4) selain itu sebagai seorang calon guru harus memahami dan berpedoman kepada kode etik guru.

Target minimal kompetensi sosial di atas, meskipun sudah terperinci apa yang perlu dinilai dari mahasiswa praktikan, namun deskripsi indikator yang dinilai beserta rubriknya belum ada, karena penilaian yang digunakan untuk kompetensi sosial selama ini melalui pengamatan teman sejawat dari mahasiswa dan guru pamong selama berada di lokasi tanpa ada instrumen penilaian. Dengan demikian perlu dilakukan pengembangan instrumen penilaian yang mengukur kompetensi ini. Pengembangan instrumen penilaian pada kompetensi ini, perlu memperhatikan itemitem yang ada pada instrumen yang digunakan dalam menilai kompetensi sosial guru di Indonesia seperti instrumen pada uji kompetensi guru (UKG), instrumen penilaian kinerja guru kelas/mata pelajaran yaitu: 1) bersikap inklusif, bertindak objektif, serta tidak diskriminatif karena pertimbangan jenis kelamin, agama, ras, kondisi fisik, latar belakang keluarga, dan status sosial ekonomi, 2) berkomunikasi secara efektif, empatik, dan santun dengan sesama pendidik, tenaga kependidikan, orang tua, dan masyarakat, 3) beradaptasi di tempat bertugas yang memiliki keragaman social budaya, 4) berkomunikasi dengan komunitas profesi sendiri dan profesi lain secara lisan dan tulisan atau bentuk lain.

Demikian halnya kompetensi profesional pada indikator kualitas penguasaan materi menggunakan kalimat yang menimbulkan penafsiran yang keliru seperti menggunakan istilah dalil, rumus atau generalisasi yang tidak terinci secara jelas. Hanya sebagian kecil dosen pembimbing yang melakukan penilaian melalui pengamatan pada saat ujian praktik mengajar, dengan alasan kesibukan, itupun tidak mengisi instrumen penilaian secara lengkap bahkan langsung memberi nilai 
akhir.Instrumen yang ada dianggap membingungkan serta tidak ada panduan penskoran secara jelas. Selain itu, penilaian yang dilakukan seperti pada kompetensi pedagogik hanya pada sisi teknik persiapan pembelajaran yang dibuat oleh mahasiswa praktikan dalam bentuk Rencana Pelaksanaan Pembelajaran (RPP), sementara pada proses pembelajaran di kelas kurang diperhatikan, bahkan ada dosen pembimbing menyerahkan tugas sepenuhnya pada guru pamong dalam melakukan penilaian terutama saat mahasiswa ujian praktik mengajar dengan alasan kesibukan.

\section{SIMPULAN}

Permasalahan umum dan utama dalam penilaian PPL mahasiswa di Fakultas Ilmu Tarbiyah dan Keguruan selama ini adalah model penilaiannya. Instrumen penilaian yang mampu mengungkap tingkat kompetensi mahasiswa praktikan yang dilengkapi dengan rubrik penskoran ternyata belum dapat dipenuhi dalam buku Panduan PPL yang ada. Selain itu, ketidakpahaman dalam pengisian instrumen penilaian PPL membuat dosen dan guru pamong tidak mengisi instrument penilaan.Sehingga dosen pembimbing dalam memberi nilai mahasiswa hanya melihat kelengkapan laporan PPLT.Apabila laporan lengkap serta tersusun rapi, maka mahasiswa yang bersangkutan dinyatakan lulus dan diberi nilai tinggi. Hal itu mengindikasikan bahwa ketidakpahaman pengisian instrumen penilaian dan penskoran yang digunakan, menyebabkan penilaian yang dilakukan oleh dosen pembimbing dan guru pamong terhadap mahasiswa praktikan belum terlaksana dengan baik serta belum optimal.

Kurang adanya kesamaan pemahaman dosen pembimbing serta guru pamong tentang perbedaan antara bobot dan nilai yang ada dalam instrumen. Secara garis besar mereka beranggapan ;a) bobot sama halnya dengan nilai tidak ada perbedaan istilah, b) bobot dan nilai sama-sama berwujud angka, c) nilai melambangkan kompetensi yang dimiliki mahasiswa secara keseluruhan berdasarkan bobot dari setiap indikator yang dinilai, d) bobot merupakan patokan dalam memberi nilai, e) bobot berbentuk angka sementara nilai berbentuk huruf, f) bobot dan nilai sama-sama menunjukan hasil pekerjaan. Temuan ini mengindikasikan bahwa para dosen pembimbing dan guru pamong dalam memaknai istilah bobot sama dengan nilai. Mereka mengaku lebih familiar dengan istilah nilai dan skor ketimbang istilah bobot. Pada realitanya persepsi ini keliru.Adanya simpang siur dalam memahami istilah

> | Lian G. Otaya | Realitas Penilaian Praktik Pengalaman Lapangan Pada Perguruan Tinggi Keagamaan Islam Dan Tantangannya di Era Millenial 
tersebut, menyebabkan mereka dalam menilai tidak memperhatikan bobot dari setiap indikator yang dinilai, melainkan langsung mencentang atau memberi tanda check list $(\sqrt{ })$ pada setiap sub indikator atau aspek yang dinilai dari masing-masing indikator.

Mencermati berbagai realita yang dihadapi dalam penilaian PPL Mahasiswa PPL di Fakultas IImu Tarbiyah dan Keguruan agar outputnya mampu menghasilkan dan mempersiapkan calon guru yang memiliki employability skills yang memadai, maka model penilaian yang digunakan selama ini perlu dikembangkan secara utuh dari kompetensi pedagogik, kompetensi profesional, kompetensi sosial dan kompetensi kepribadian. Keempat kompetensi tersebut terintegrasi dalam penilaian mahasiswa praktikan selama di sekolah/ madrasah latihan. Para mahasiswa praktik pengalaman mahasiswa, tidak hanya dituntut menggunakan pengetahuan dan keterampilan akademik yang telah diperoleh melalui perkuliahan sesuai dengan tuntutan nyata dalam situasi kerja, tetapi para mahasiswa juga dituntut untuk mendapat pengalaman mengajar secara profesional serta mengintegrasikan pengalamannya itu ke dalam pola perilaku dirinya sebagai pribadi yang efektif dan produktif. Model penilaian yang dikembangkan untuk setiap kompetensi yang dinilai harus disesuaikan dengan perubahan dan tuntutan kurikulum yang berlaku.

\section{DAFTAR PUSTAKA}

Butler, B. M., \& Cuenca, A. 2012. "Conceptualizing the roles of mentors during student teaching". Action in Teacher education, 34, 296-308. http://dx.doi.org/10.1080/ 01626620.2012 .717012 .

Cohen, E., Hoz, R., \& Kaplan, H. 2013. "The practicum in preservice teacher education: A review of empirical studies£. Teaching Education, 24(4), 345-380. doi:10.1080/10476210.2012.711815.

Creswell, J. 2003. Research Design: Qualitative, Quantitative, and Mixed Method Approaches. Thousand Oaks, CA: Sage Publications.

Gareis, C. R., \& Grant, L. W. 2014. "The efficacy of training cooperating teachers". Teaching and Teacher Education, 39, 77-88. http://dx.doi.org/10.1016/j. tate.2013.12.007.

Hashona, A.H. 2014. "Kajian pelaksanaan praktik pengalaman lapangan (PPL) mahasiswa fakultas ilmu tarbiyah dan keguruan IAIN Walisongo Semarang". Cendekia, 12(7), 333-351. 
Khuziakhmetov, A.N. 2016. "Social competence formation of students in the process of students self-government". Mathematics Education, 11(4), 81-89.

Ku, H. Y., Kaufeld, K., Hess, C., \& Sheehan, E. 2012. "An evaluation on the student teaching triad model". Society for Information Technology \& Teacher Education International Conference, 1, 1927-1932. Retrieved from https://www.editlib.or.

Mahanani, A. 2011. Buku pintar PLPG. Yogyakarta: Araska.

Moseley, J.L.\& Hastings, N.B. 2005. "The forgotten link om the intervention chain". Performance Improvement, 44, 4, Diakses tanggal 17 Agustus 2017, dari http://proquest.umi.com/pqdweb.

Muhammad Azeem. 2011. "Problems of prospective teachers during teaching practice". Academic Research International, 1(11), 308-316.

Rofiq. 2008. "Efektivitas Praktik Pengalaman Lapangan Jurusan Pendidikan Agama Islam Fakultas Tarbiyah Universitas Islam Negeri Sunan Kalijaga Yogyakarta Tahun Akademik 2006-2007”. Aplikasia, Jurnal Aplikasi Ilmu-IImu Agama, Vol. IX No. 2, 117-136.

Sagala, S. 2011. Kemampuan profesional guru dan tenaga kependidikan. Bandung: Alfabeta.

Tim Penyusun. 2013. Pedoman Praktik Profesi Keguruan Terpadu (PPKT), Jakarta: Laboratorium FITK UIN Jakarta.

Whitebook, M., Austin, L. J., Ryan, S., Kipnis, F., Almaraz, M., \& Sakai, L. 2012. By default or by design? Variations in higher education programs for early care and education teachers and their implications for research methodology, policy, and practice. (Report). Berkeley, CA: Center for the Study of Child Care Employment.

Wilkerson, J.R., \& Lang W.S. 2007. Assessing teacher competency: Five standardbased steos to valid measurement using the CAATS model. California: Corwin Press a Sage Publication Company.

Yulianto, A., \& Khafid, M. 2016. "Pengaruh praktik pengalaman lapangan (PPL), minat menjadi guru, dan prestasi belajar terhadap kesiapan mahasiswa menjadi guru yang professional". Economic Education Analysis Journal, 5(1), 100-114. http://journal.unnes.ac.id/sju/index.php/eeaj 
54 | Jurnal Tarbawi Vol. 15. No. 2. Juli - Desember 2018 